\title{
Proximate and fatty acid composition of cooked South African Cape snoek (Thyrsites atun)
}

AUTHORS:

Suné S. Henning ${ }^{1}$

Louwrens C. Hoffman ${ }^{2}$

\section{AFFILIATIONS:}

'Department of Food Technology,

Cape Peninsula University

of Technology, Cape Town,

South Africa

'Department of Animal Sciences,

Stellenbosch University,

Stellenbosch, South Africa

\section{CORRESPONDENCE TO:}

Suné Henning

\section{EMAIL:}

hennings@cput.ac.za

\section{DATES:}

Received: 31 May 2016

Revised: 05 0ct. 2016

Accepted: 05 Jan. 2017

\section{KEYWORDS:}

eicosapentaenoic acid docosahexaenoic acid, protein content; boiling; snoek

\section{HOW TO CITE:}

Henning SS, Hoffman LC. Proximate and fatty acid composition of cooked South African Cape snoek (Thyrsites atun). S Afr J Sci. 2017;113(5/6), Art. \#2016-0161, 4 pages. http://dx.doi.org/10.17159/ sajs.2017/20160161

\section{ARTICLE INCLUDES: \\ $\times$ Supplementary material $\times$ Data set}

\section{FUNDING:}

None
Cape snoek (Thyrsites atun) is an important source of protein for people in South Africa; however, nutritional information thereof is limited. The proximate and fatty acid compositions of raw and cooked $\left(80{ }^{\circ} \mathrm{C}\right)$ snoek muscles were determined according to official AOAC methods. The mean moisture, ash, total lipids and protein for raw snoek were $72.8 \pm 1.86 \%, 1.3 \pm 0.09 \%, 4.0 \pm 1.16$ and $21.5 \pm 1.35 \%$, respectively. Cape snoek is very high in palmitic acid $(24.65 \pm 1.43 \%)$, oleic acid $(18.21 \pm 2.64 \%)$, eicosapentaenoic acid (EPA, 9.11 $\pm 2.06 \%$ ) and docosahexaenoic acid (DHA, 19.70 $\pm 3.25 \%$ ). With the exception of total lipids, cooking significantly reduced moisture $(69.40 \pm 2.03 \%)$ and ash $(1.12 \pm 0.12 \%)$, and increased protein $(24.47 \pm 1.39 \%)$ content. It is concluded that Cape snoek is very high in protein and can be classified as a low-fat fish which is rich in EPA and DHA.

\section{Significance:}

- Cape snoek is a low-fat fish, containing less than $4 \%$ fat, and is high in EPA $(9.11 \pm 2.06 \%)$ and DHA $(19.70 \pm 3.25 \%)$.

- $\quad$ Cape snoek is thus a healthy, cheap and high-protein food source, with a high content of omega-3 fatty acids.

\section{Introduction}

Thyrsites atun (Cape snoek) is a medium-sized, pelagic predator and has been an important commercial marine fish species in South Africa since the early 1800s. ${ }^{1}$ Initially, snoek was caught with hand lines and trawled after 1960 , but today it forms part of a diverse informal, artisanal and commercial fishery industry. South African snoek can be found in temperate waters from the West Coast to the East Coast of South Africa. ${ }^{1,2}$ In the Cape (West Coast) region of South Africa, snoek is an important source of readily available and affordable protein to many medium- and low-income households. Snoek is prepared in several different ways, from oven baking and microwave cooking to cooking over flames or coals (locally known as 'braaing') and smoking.

Among the food resources of the world, fish and fishery products are very important sources of animal protein. The high nutritional quality and health benefits of consuming marine fish and fishery products have been well documented over many years ${ }^{3-7}$ as the fishing industry has become a fast-growing industry focused on healthy eating. Most of the focus has been on the health benefits of $n-3$ polyunsaturated fatty acids (PUFAs); however, besides essential n-3 PUFAs, fish are a major source of high-quality protein because of the balanced content in amino acids, especially essential amino acids necessary for physical and mental well-being. ${ }^{8}$ Marine fish also provide certain vitamins and minerals such as iodine, selenium and zinc. ${ }^{9,10}$

Fish are classified as either fatty (>10\% fat), medium fat (5-10\% fat), low fat ( $2-4 \%$ fat) or lean $(<2 \%$ fat) according to the percentage fat in the muscle. ${ }^{11,12}$ In general, marine fish species are high in n-3 PUFAs, particularly eicosapentaenoic acid (ECP, C20:5n-3) and docosahexaenoic acid (DHA, C22:6n-3), as well as in monoenes such as $\mathrm{C} 18: 1 \mathrm{n}-9$, and the saturated fatty acid C16:0 (palmitic acid). The fatty acid profile of marine fish is dependent on their type of diet. Within inshore waters, adult $(>75 \mathrm{~cm})$, sub-adult $(50-75 \mathrm{~cm})$ and juvenile $(25-49 \mathrm{~cm})$ Cape snoek feed mainly on anchovies (Engraulis capensis) and sardines (Sardinops ocellatus), while in offshore waters, adult snoek mainly feed on sardines, round herring (Spratelloides robustus) and hake (Merluccius spp.). ${ }^{1}$

In general, fish muscle contains very low quantities of carbohydrates with the percentage carbohydrates, depending on the species of fish, ranging between $0.2 \%$ and $1.5 \%{ }^{13}$; this low percentage results in fish muscle obtaining a relatively high post-mortem $\mathrm{pH}$ compared to that of mammalian muscle. The $\mathrm{pH}$ in fish muscle drops from 7.0 to 6.5 during early post-mortem storage ${ }^{13,14}$, whereas in bovine muscle, the $\mathrm{pH}$ falls to between 5.4 and 5.7 within $24 \mathrm{~h}$ post-mortem. The high post-mortem $\mathrm{pH}$ content of fish muscle enables the rapid growth of naturally occurring, Gram-negative, pH-sensitive psychrotrophic bacteria, such as Pseudomonas and Shewanella; these bacteria can reach numbers of up to $10^{6}-10^{8} \mathrm{cfu} / \mathrm{g}$ within a few days ${ }^{13}$ and result in rapid spoilage of fish.

Few studies have examined the nutritional composition of South African marine fish species. Information available about the nutritional value of raw and cooked Cape snoek is scarce. It is becoming increasingly difficult to put aside the fact that proximate analysis has a fundamental function in the application of various processing methods. Proximate analysis is the determination of major nutrients through assessment of the moisture, ash, crude protein, crude fibre and carbohydrate contents. In addition, proximate analysis makes a critical contribution on raw material quality aspects, sensory evaluations, consumer perception and shelf life. The aim of this study was therefore to determine the proximate and fatty acid compositions of raw and cooked Cape snoek (Thyrsites atun) in order to quantify the nutritional value and make the information available to consumers and processors, for nutritional tables for South African foodstuffs and for academic databases. 


\section{Materials and methods}

\section{Sample preparation}

In total, 10 flecked (eviscerated but not filleted) snoek (Thyrsites atun), caught at Stompneus Bay (Cape Town, South Africa) during the winter month of June, were collected from a fish-processing facility in Brackenfell, Cape Town. The mean weight of the flecked snoek, with head and tail still attached, was $1.93 \pm 0.37 \mathrm{~kg}$. The snoek were transported (duration of about $30 \mathrm{~min}$ ) on ice in cooler boxes to the laboratories of the Department of Animal Sciences, Stellenbosch University (Stellenbosch, South Africa). Muscle samples of 100-200 g were removed from the left and right sides of each flecked snoek at a location from the centre (abdominal area) of each flecked fish such that both dorsal and ventral muscles were sampled. Samples from the left sides were kept raw, while samples from the right sides were placed into a plastic bag and cooked in a water bath at $80^{\circ} \mathrm{C}$ (boiling) for $1 \mathrm{~h}$. Thereafter, individual samples were vacuum packed and frozen at $-20^{\circ} \mathrm{C}$ until proximate and fatty acid analyses were performed.

\section{Proximate analysis}

The skin and bones were removed from all tissue samples before the samples were homogenised. All proximate analyses were done in duplicate. Moisture content was determined by drying the homogenised sample in a drying oven at $100{ }^{\circ} \mathrm{C}$ for $24 \mathrm{~h}$. The dried samples were allowed to $\mathrm{cool}$ in a desiccator for $30 \mathrm{~min}$. The samples were weighed and the moisture content was determined according to the Association of Official Analytical Chemists (AOAC)'s $\mathrm{s}^{15}$ official method 934.01. Crude protein was determined by the Kjeldahl's method on a FP-428 Nitrogen and Protein Determinator (Leco, Saint Joseph, MI, USA). The nitrogen content was multiplied with the appropriate factor $(6.2 \times \mathrm{N})$ according to the $A O A C^{16}$ official method 992.15. Total lipids were determined by solvent extraction according to the method described by Lee et al. ${ }^{17}$ Ash was determined according to the official $A 0 A C^{18}$ method 942.05 . Carbohydrates ( $\mathrm{CHO})$ were calculated as follows:

$\mathrm{CHO}(\mathrm{g} / 100 \mathrm{~g})=$ dry matter - protein - fat - ash,

where dry matter is calculated as 100 - moisture content.

\section{Fatty acid analysis}

The fatty acid profiles for both the raw and cooked samples were determined by gas chromatography with the following specifications: column, SP-2560, $100 \mathrm{~m} \times 0.25 \mathrm{~mm}$ ID, $0.20 \mu \mathrm{m}$ film (cat no. 24056); oven of $140{ }^{\circ} \mathrm{C}$ for 5 min to $240{ }^{\circ} \mathrm{C}$ at $4{ }^{\circ} \mathrm{C} / \mathrm{min}$; helium at $20 \mathrm{~cm} / \mathrm{s}$ as carrier gas; FID detector, $260^{\circ} \mathrm{C}$; and injection at $1 \mu \mathrm{L}, 260^{\circ} \mathrm{C}$ and split of 100:1. C17:0 was used as the internal standard and to facilitate calculation of the actual amount of individual fatty acids. Fatty acid methyl esters (FAME) were identified by using differences in retention times, compared with the retention time of the standard FAME mixture (Supelco 37 Component FAME mix, C4-C24, cat no. 47885-U, Bellefonte, PA, USA). The fatty acids in grams were calculated and are expressed as a percentage based on the internal standard C17:0.

\section{Statistical analysis}

The proximate and fatty acid data were subjected to a one-way analysis of variance using SAS version 9.0 statistical software. Significant differences between means were determined by least significant difference, with a significance level of 0.05 .

\section{Results}

The proximate composition of raw and cooked Cape snoek muscle is summarised in Table 1. The mean percentages of (the percentage value is equivalent to $\mathrm{g} / 100 \mathrm{~g}$ muscle tissue or meat) moisture, ash, total lipids and protein for raw Cape snoek were $72.8 \pm 1.86 \%, 1.3 \pm 0.09 \%$, $4.0 \pm 1.16 \%$ and $21.5 \pm 1.35 \%$, respectively. The carbohydrate content of raw and cooked snoek was calculated as $0.5 \pm 0.80 \%$ and $0.7 \pm 1.60 \%$, respectively.
Table 1: Proximate composition (\% mean \pm standard deviation) of raw and cooked ${ }^{\dagger}$ Cape snoek (Thyrsites atun) muscle

\begin{tabular}{l|c|c|c|c|c}
\hline \hline & $\begin{array}{c}\text { Moisture } \\
(\mathbf{\%})\end{array}$ & $\begin{array}{c}\text { Ash } \\
\mathbf{( \% )}\end{array}$ & $\begin{array}{c}\text { Total lipids } \\
\mathbf{( \% )}\end{array}$ & $\begin{array}{c}\text { Protein } \\
(\mathbf{\%})\end{array}$ & $\begin{array}{c}\text { Carbohydrates } \\
(\mathbf{\%})\end{array}$ \\
\hline Raw & $72.8^{\mathrm{a}} \pm 1.86$ & $1.3^{\mathrm{a}} \pm 0.09$ & $4.0^{\mathrm{a}} \pm 1.16$ & $21.5^{\mathrm{a}} \pm 1.35$ & $0.5^{\mathrm{a}} \pm 0.80$ \\
\hline Cooked & $69.4^{\mathrm{b}} \pm 2.03$ & $1.1^{\mathrm{b}} \pm 0.12$ & $4.3^{\mathrm{a}} \pm 1.01$ & $24.5^{\mathrm{b}} \pm 1.39$ & $0.7^{\mathrm{b}} \pm 1.60$ \\
\hline
\end{tabular}

${ }^{+}$Samples were cooked in a water bath at $80^{\circ} \mathrm{C}$.

a,bWithin a column, values with different superscripts are significantly different $(\mathrm{p}<0.05)$.

Table 2: $\quad$ Fatty acid composition (\% mean \pm standard deviation) of raw and cooked ${ }^{\dagger}$ Cape snoek (Thyrsites atun) muscle

\begin{tabular}{|c|c|c|}
\hline Fatty acid & Raw snoek muscle & Cooked snoek muscle \\
\hline $\mathrm{C} 14: 0$ & $3.60^{\mathrm{a}} \pm 1.62$ & $3.51^{\mathrm{a}} \pm 1.03$ \\
\hline C15:0 & $0.44^{\mathrm{a}} \pm 0.06$ & $0.41^{\mathrm{a}} \pm 0.59$ \\
\hline C16:0 & $24.65^{\mathrm{a}} \pm 1.43$ & $23.21^{b} \pm 0.99$ \\
\hline C18:0 & $6.87^{\mathrm{a}} \pm 1.40$ & $6.61^{\mathrm{a}} \pm 1.25$ \\
\hline $\mathrm{C} 20: 0$ & $0.13^{a} \pm 0.02$ & $0.14^{a} \pm 0.03$ \\
\hline C21:0 & $0.19^{\mathrm{a}} \pm 0.01$ & $0.19^{\mathrm{a}} \pm 0.04$ \\
\hline $\mathrm{C} 22: 0$ & $0.09^{a} \pm 0.05$ & $0.11^{b} \pm 0.06$ \\
\hline $\mathrm{C} 24: 0$ & $0.21^{\mathrm{a}} \pm 0.09$ & $0.25^{b} \pm 0.06$ \\
\hline Total SFAs & $36.36^{a} \pm 1.67$ & $34.29^{b} \pm 1.70$ \\
\hline C14:1 & $0.17^{a} \pm 0.02$ & $0.17^{\mathrm{a}} \pm 0.03$ \\
\hline C15:1 & $0.10^{\mathrm{a}} \pm 0.01$ & $0.09^{a} \pm 0.01$ \\
\hline C16:1 & $5.61^{\mathrm{a}} \pm 1.39$ & $5.47^{\mathrm{a}} \pm 1.24$ \\
\hline $\mathrm{C} 20: 1$ & $3.07^{a} \pm 1.39$ & $4.16^{b} \pm 1.12$ \\
\hline C24:1 & $0.38^{\mathrm{a}} \pm 0.05$ & $0.40^{\mathrm{a}} \pm 0.05$ \\
\hline C18:1n-9c & $18.21^{\mathrm{a}} \pm 2.64$ & $17.95^{\mathrm{a}} \pm 2.66$ \\
\hline C18:1n-9t & $0.15^{\mathrm{a}} \pm 0.05$ & $0.17^{a} \pm 0.05$ \\
\hline C22:1n-9 & $2.42^{\mathrm{a}} \pm 1.23$ & $2.77^{b} \pm 1.06$ \\
\hline Total MUFAs & $31.24^{\mathrm{a}} \pm 5.01$ & $31.56^{\mathrm{a}} \pm 4.93$ \\
\hline$C 18: 2 n-6 c$ & $1.82^{\mathrm{a}} \pm 0.96$ & $1.26^{a} \pm 0.09$ \\
\hline C18:2n-6t & $0.05^{\mathrm{a}} \pm 0.02$ & $0.05^{\mathrm{a}} \pm 0.03$ \\
\hline C18:3n-6 & $0.25^{\mathrm{a}} \pm 0.05$ & $0.26^{a} \pm 0.04$ \\
\hline C18:3n-3 & $0.70^{\mathrm{a}} \pm 0.09$ & $0.68^{a} \pm 0.07$ \\
\hline $\mathrm{C} 20: 2$ & $0.08^{a} \pm 0.02$ & $0.09^{a} \pm 0.02$ \\
\hline $\mathrm{C} 20: 3 \mathrm{n}-3$ & $0.09^{a} \pm 0.03$ & $0.09^{a} \pm 0.04$ \\
\hline C20:3n-6 & $0.27^{a} \pm 0.07$ & $0.34^{b} \pm 0.10$ \\
\hline C20:4n-6 & $1.06^{a} \pm 0.08$ & $1.11^{\mathrm{a}} \pm 0.17$ \\
\hline C20:5n-3 (EPA) & $9.11^{\mathrm{a}} \pm 2.06$ & $10.13^{b} \pm 2.01$ \\
\hline C22:6n-3 (DHA) & $19.70^{\mathrm{a}} \pm 3.25$ & $20.28^{b} \pm 4.47$ \\
\hline Total PUFAs & $32.40^{\mathrm{a}} \pm 4.11$ & $34.15^{\mathrm{a}} \pm 4.39$ \\
\hline PUFA:SFA & $0.89^{\mathrm{a}} \pm 0.11$ & $1.00^{b} \pm 0.13$ \\
\hline$n-6: n-3$ & $0.12^{a} \pm 0.04$ & $0.10^{\mathrm{a}} \pm 0.01$ \\
\hline
\end{tabular}

SFA, saturated fatty acids; MUFA, monounsaturated fatty acids; EPA, eicosapentaenoic acid; DHA, docosahexaenoic acid; PUFA, polyunsaturated fatty acids

tSamples were cooked in a water bath at $80^{\circ} \mathrm{C}$.

${ }^{a, b}$ Within a row, values with different superscripts are significantly different $(p<0.05)$. 
Cape snoek is very high in palmitic acid (C16:0), oleic acid (C18:1n-9c), eicosapentaenoic acid (EPA) and docosahexaenoic acid (DHA) (Table 2). Marine fish, in general, are characteristically low in linoleic and linolenic acid, ${ }^{3}$ and Cape snoek are no exception with $1.26 \pm 0.09 \%$ linoleic acid and $0.68 \pm 0.07 \% \alpha$-linolenic acid, respectively, for cooked samples (Table 2). Marine fish species are further characterised by high levels of long-chain n-3 PUFAs and low levels of n-6 fatty acids, which gives them a high $n-3: n-6$ ratio (or low n-6:n-3 ratio), which is nutritionally seen as beneficial to human health and well-being.,19 Cape snoek samples had very low $n-6: n-3$ ratios of $0.12 \pm 0.04$ for raw samples and $0.01 \pm 0.01$ for cooked samples (Table 2), making Cape snoek a healthy fish for human consumption.

Cooking the fish at $80{ }^{\circ} \mathrm{C}$ significantly $(p<0.05)$ increased the concentration of behenic (C22:0), ligoceric (C24:0), gondoic (C20:1), erucic (C22:1n-9) and homo-g-linolenic (C20:3n-6) acids, ECP and DHA, but not palmitic acid. Similar to results found by Türkkan et al. ${ }^{20}$ for baked seabass (Dicentrarchus labrax), the total saturated fatty acid (SFA) content of raw Cape snoek reduced from $36.36 \pm 1.67 \%$ to $34.29 \pm 1.70 \%$ for cooked samples $(p<0.05$; Table 2$)$. In contrast, cooking had no significant effect on monounsaturated fatty acids (MUFAs) and PUFAs of snoek samples.

\section{Discussion}

Cooked snoek muscle had a significantly lower $(p<0.05)$ moisture content than raw snoek. Cooking methods such as boiling and microwave cooking significantly decrease moisture content in fish muscle. ${ }^{20-23}$ In contrast to the findings of Gokoglu et al. ${ }^{21}$ and Türkkan et al. ${ }^{20}$, in which cooked samples had higher ash content than raw samples, cooked snoek samples had a lower ash content than raw samples. The reason for this finding is unclear as, similarly to the studies conducted by Gokoglu et al. ${ }^{21}$ and Türkkan et al. ${ }^{20}$, the skin from all snoek samples was removed before proximate analysis was performed. It could be argued that the minerals (ash) leached out during cooking (linked to the $\sim 3 \%$ moisture loss experienced; Table 1); however, more research is required to quantify this assumption. Similarly to other research studies ${ }^{20-22}$, cooking (boiling) significantly increased the protein $(24.47 \pm 1.39 \%$ for cooked vs $21.48 \pm 1.35 \%$ for raw) content of Cape snoek but not the total lipid content $(4.34 \pm 1.01 \%$ for cooked vs $3.99 \pm 1.16 \%$ for raw). It may be argued that a $\sim 3 \%$ moisture loss concentrated the crude protein, carbohydrate and fat contents which thus showed an increase.

According to Koubaa et al. ${ }^{12}$ and Huynh and Kitts ${ }^{11}$, fish are classified as fatty ( $>10 \%$ fat), medium fat ( $5-10 \%$ fat), low fat $(<5 \%$ fat) or lean $(<2 \%)$ according to the percentage fat in the muscle. With a total lipid content of $4.0 \pm 1.16 \%$ for raw Cape snoek and $4.3 \pm 1.01 \%$ for cooked snoek muscle (skin removed), Cape snoek may be classified as a lowfat fish. Cape snoek contains a similar amount of fat $(4.0 \pm 1.16 \%)$ to pink salmon (Oncorhynchus gorbusha) fillets $(3.95 \pm 0.79 \%) .{ }^{11}$ However, the proximate composition of South African Cape hake (Merluccius capensis) and South African pilchards (Sardinops ocellatus) have not been published and thus a comparison with other economically important South African marine fish species is difficult.

When comparing the protein content of raw Cape snoek to that of the raw muscle of other marine fish species - such as European hake (Merluccius merluccius) with a protein content of $17.88 \pm 0.70 \%{ }^{24}$, seabass (Dicentrarchus labrax; $18.47 \pm 0.43 \%$ ) $^{20}$ and cod (Gadus morhua callarias; $17.4 \pm 0.9 \%)^{7}$ - raw snoek muscle has a high protein content of $21.5 \pm 1.35 \%$. Compared with the protein content of freshwater fish species, such as rainbow trout (Oncorhynchus mykiss) with a protein content of $19.80 \pm 0.04 \%{ }^{21}$, catfish (Clarias gariepinus; $\left.16.24 \%\right)^{25}$ and silver catfish (Rhamdia quelen; $15.5 \pm 0.19 \%)^{22}$, Cape snoek can be seen as a fish with high protein content. It may be hypothesised that the piscivorous diet of Cape snoek may partly contribute to the high protein content of Cape snoek muscle, but European hake is also piscivorous, feeding primarily on blue whiting (Microsmesistius poutassou), poor cod (Trisopterus minutus) and Norway pout (Trisopterus esmarki) ${ }^{26}$, while Cape snoek feeds on crustaceans, cephalopods and small fish such as anchovies and pilchards, as well as round herring and hake (Merluccius spp.) ${ }^{1}$. It must further be kept in mind that the nutritional composition of fish, including the fatty acid composition, is influenced by factors such as season of the year, feeding habits, and sex, age and maturity of the fish. $711,27,28$

In general, fish muscle contains very low quantities of carbohydrates. The percentage carbohydrates in fish muscle, depending on the species of fish, ranges between $0.2 \%$ and $1.5 \%,{ }^{13}$ resulting in fish muscle having a relatively high post-mortem $\mathrm{pH}$ as compared to that of mammalian muscle. The $\mathrm{pH}$ in fish muscle drops from 7.0 to 6.5 during early postmortem storage ${ }^{13,14}$ while in bovine muscle the $\mathrm{pH}$ falls to $\sim 5.4$ within $24 \mathrm{~h}$ post-mortem. The carbohydrate contents of raw and cooked snoek were calculated as $0.5 \pm 0.80 \%$ and $0.7 \pm 1.60 \%$, respectively (Table 1 ).

In comparison with other economically important marine fish species, raw Cape snoek muscle has a similar EPA and DHA content as pink salmon muscle (Onchorhynchus gorbuscha; EPA of $8.17 \pm 0.78 \%$ and DHA of $19.34 \pm 1.11 \%),{ }^{11}$ but lower than that of Pacific hake (Merluccius productus; EPA of $12.91 \pm 1.51 \%$ and DHA of $22.08 \pm 1.28 \%$ ) and sardine (Sardinops sagax; EPA of $11.43 \pm 1.08 \%$ and DHA of $32.65 \pm 3.44 \%$ ), making Cape snoek a good source of DHA.

The fatty acid content of the raw Cape snoek was similar to that reported for this species collected off the coast of southeastern Australia, ${ }^{29}$ although the reported data were from only three fish. The raw Cape snoek had higher SFA, lower MUFA and similar PUFA content to that from Australia. However, the n-6:n-3 was similar between the two studies (South Africa $=0.12$; Australia $=0.21$ ).

Boiling Cape snoek muscle in water significantly reduced the fatty acid content, while not altering the MUFA and PUFA contents, making cooking in water a healthy option for preparing Cape snoek. In addition, Cape snoek seems to contain a good balance between SFAs, MUFAs, and PUFAs, with a PUFA:SFA ratio of $0.89 \pm 0.11$ for raw samples and $1.00 \pm 0.13$ for cooked samples. A PUFA:SFA ratio of $\geq 0.45$ is recommended in the UK. ${ }^{30}$

\section{Conclusions}

Cooking Cape snoek by boiling at $80^{\circ} \mathrm{C}$ for $1 \mathrm{~h}$ significantly increased the protein content, reduced the moisture and ash contents, and had no effect on the total lipid content of skinless muscle. The proximate composition of Cape snoek has not been published before and it is concluded, from the results of this study, that raw Cape snoek is a medium-fat (5-10\% fat) to low-fat (2-4\% fat) fish containing less than $4 \%$ fat; however, cooking increased (concentrated) the fat content to just above $4 \%$. Cape snoek also has a relatively high protein content compared to other economically important marine fish species, making it a very good source of animal protein. However, further studies are recommended to determine the proximate and fatty acid profile of other economically important South African marine species, such as Cape hake (Merluccius capensis), Cape dory (Zeus capensis) and South African pilchard (Sardinops ocellatus). It is further suggested to determine the total lipid and fatty acid composition of Cape snoek skin, because in many cases the snoek is cooked with the skin intact and/or consumed with the skin. It is also suggested to investigate the effects of different cooking methods on the proximate and fatty acid composition of Cape snoek.

\section{Acknowledgements}

We acknowledge Die Visfabriek (Brackenfell, Cape Town) for supplying and flecking of the Cape snoek samples.

\section{Authors' contributions}

S.S.H. wrote the first and final drafts; L.C.H. assisted with editing.

\section{References}

1. Griffiths MH. Life history of South African snoek, Thyrsites atun: A pelagic predator of the Benguela ecosystem - Pisces: Gempylidae. Fish Bull. 2002;100:690-710. 
2. Crawford RJM, Underhill LG, Venter JD. Handline catches and stock identity of snoek Thyrsites atun off South Africa and Namibia. S Afr J Marine Sci. 1990;9(1):95-99. https://doi.org/10.2989/025776190784378745

3. Steffens W. Effects of variation in essential fatty acids in fish feeds on nutritive value of freshwater fish for humans. Aquaculture. 1997;151:97-119. https:// doi.org/10.1016/S0044-8486(96)01493-7

4. Simopoulos AP. The importance of the ratio of omega-6/omega-3 essential fatty acids. Biomed Pharmacother. 2002;56:365-379. https://doi. org/10.1016/S0753-3322(02)00253-6

5. Moyad MA. An introduction to dietary/supplemental omega-3 fatty acids for general health and prevention: Part II. Seminar article. Urol Oncol. 2005;23:36-48. https://doi.org/10.1016/j.urolonc.2005.03.001

6. Domingo JL. Omega-3 fatty acids and the benefits of fish consumption: Is all that glitters gold? A review. Environ Int. 2007;33:993-998. https://doi. org/10.1016/j.envint.2007.05.001

7. Usydus Z, Szlinder-Richert J, Adamczyk M, Szatkowska U. Marine and farmed fish in the Polish market: Comparison of the nutritional value. Food Chem. 2011;126:78-84. https://doi.org/10.1016/j.foodchem.2010.10.080

8. Schiepers OJG, De Groot RHM, Jolles J, Van Boxtel MPJ. Fish consumption, not fatty acid status, is related to quality of life in a healthy population. Prostaglandins Leukot Essent Fatty Acids. 2010;83:31-35. https://doi. org/10.1016/j.plefa.2010.02.030

9. Vlieg P. Selenium concentration of the edible part of 74 New Zealand fish species. J Food Compost Anal. 1990;3:67-72. https://doi.org/10.1016/08891575(90)90010-J

10. Kim Y. Vitamins. In: Nollet LML, Toldrá F, editors. Handbook of seafood and seafood products analysis. London: CRC Press; 2010. p. 327-350. https:// doi.org/10.1201/9781420046359-c19

11. Huynh MD, Kitts DD. Evaluating nutritional quality of Pacific fish species form fatty acid signatures. Food Chem. 2009;114:912-918. https://doi. org/10.1016/j.foodchem.2008.10.038

12. Koubaa A, Abdelmouleh A, Bouain A, Mihoubi NB. Experimental and statistical investigations of the global chemical composition of six trawling fish of the Gulf of Gabés (Mediterranean Sea). J Marine Biol Association UK. 2010:1-7. https://doi.org/10.1017/S0025315410000640

13. Françoise L. Occurrence and role of lactic acid bacteria in seafood products. A review. Food Microbiol. 2010;27:698-709. https://doi.org/10.1016/j. fm.2010.05.016

14. Chéret R, Delbarre-Ladrat C, De Lamballerie-Anton M, Verrez-Bagnis V. Calpain and cathepsin activities in post-mortem fish and meat muscles. Food Chem. 2007;101:1474-1479. https://doi.org/10.1016/j.foodchem.2006.04.023

15. Association of Official Analytical Chemists (AOAC). Loss on drying (moisture) at $95-100{ }^{\circ} \mathrm{C}$ for feeds. AOAC official method 934.01. In: AOAC international official methods of analysis. 17th ed. Arlington, VA: AOAC; 2002.

16. Association of Official Analytical Chemists (AOAC). Protein (crude) in animal feed and pet food. AOAC official method 992.15. In: AOAC international official methods of analysis. 17th ed. Arlington, VA: AOAC; 2002.
17. Lee CM, Trevino B, Chaiyawat M. A simple and rapid solvent extraction method for determining total lipids in fish tissue. J AOAC Int. 1996;2:79.

18. Association of Official Analytical Chemists (AOAC). Ash of animal feed. $A O A C$ official method 942.05. In: AOAC international official methods of analysis. 17th ed. Arlington, VA: AOAC; 2002.

19. Candela M, Astiasarán I, Bello J. Effects of frying and warmholding on fatty acids and cholesterol of sole (Solea solea), codfish (Gadus morrhua) and hake (Merluccius merluccius). Food Chem. 1997:58:227-231. https://doi. org/10.1016/S0308-8146(96)00169-0

20. Türkkan AU, Cakli S, Kilinc B. Effects of cooking methods on the proximate composition and fatty acid composition of seabass (Dicentrarchus labrax, Linnaeus, 1758). Food Bioprod Process. 2008;86:163-165. https://doi. org/10.1016/j.fbp.2007.10.004

21. Gokoglu N, Yerlikaya P, Cengiz E. Effects of cooking methods on the proximate composition and mineral content of rainbow trout (Oncorhynchus mykiss). Food Chem. 2004;84:19-22. https://doi.org/10.1016/S03088146(03)00161-4

22. Weber J, Bochi VC, Ribeiro CP, Victório A de M, Emanuelli T. Effect of different cooking methods on the oxidation, proximate and fatty acid composition of silver catfish (Rhamdia quelen) fillets. Food Chem. 2008;106:140-146. https://doi.org/10.1016/j.foodchem.2007.05.052

23. Ersoy B. Effects of cooking methods on the proximate, mineral and fatty acid composition of European eel (Anquilla anguilla). Int J Food Sci Tech. 2011;46:522-527. https://doi.org/10.1111/j.1365-2621.2010.02546.x

24. Roncarati A, Brambilla G, Meluzzi A, lamiceli AL, Fanelli R, Moret I, et al. Fatty acid profile and proximate composition of fillets from Engraulis encrasicholus, Mullus barbatus, Merluccius merluccius and Sarda sarda caught in Tyrrhenian, Adriatic and Ionian seas. J Appl Ichthyol. 2012;28:545552. https://doi.org/10.1111/j.1439-0426.2012.01948.x

25. Foline OF, Rachael AM, Iyabo BE, Fidelis AE. Proximate composition of catfish (Clarias gariepinus) smoked in Nigerian Stored Products Research Institute (NSPRI): Developed kiln. Int J Fish Aquaculture. 2011;3(5):95-97.

26. Osman H, Suriah AR, Law EC. Fatty acid composition and cholesterol content of selected marine fish in Malaysian waters. Food Chem. 2001;73:55-60. https://doi.org/10.1016/S0308-8146(00)00277-6

27. Du Buit MH. Diet of hake (Merluccius merluccius) in the Celtic Sea. Fish Res. 1996;28:381-394. https://doi.org/10.1016/S0165-7836(96)00516-4

28. Nakamura Y-N, Ando M, Seoka M, Kawasaki K, Tsukamasa Y. Changes of proximate and fatty acid compositions of the dorsal and ventral ordinary muscles of the full-cycle cultured Pacific bluefin tuna Thunnus orientalis with the growth. Food Chem. 2007;103:234-241. https://doi.org/10.1016/j. foodchem.2006.07.064

29. Pethybridge H, Daley R, Virtue P, Butler ECV, Cossa D, Nichols PD. Lipid and mercury profiles of 61 mid-trophic species collected off south-eastern Australia. Mar Freshw Res. 2010;61:1092-1108. https://doi.org/10.1071/ MF09237

30. Warriss PD. Meat science: An introductory text. Wallingford: CABI Publishing; 2000. 